\title{
ANALISIS KANDUNGAN TIMBAL DAN KADMIUM PADA KERANG HIJAU (Perna viridis L.) DI PERAIRAN KABUPATEN TANGERANG MENGGUNAKAN METODE SPEKTROFOTOMETRI SERAPAN ATOM
}

\section{AN ANALYSIS THE CONTENT OF LEAD AND CADMIUM IN GREEN MUSSELS (PERNA VIRIDIS L.) AT TERRITORIAL WATER OF TANGERANG DISTRICT USING ATOMIC ABSORPTION SPECTROPHOTOMETRY METHOD}

\author{
Siti Mayholida ${ }^{1 *}$, Zenith Putri Dewianti ${ }^{1}$, Diana Sylvia ${ }^{1}$ \\ ${ }^{1}$ Sekolah Tinggi Farmasi Muhammadiyah Tangerang \\ *Corresponding Author Email : sitimaykholida98@gmail.com \\ DOI: http://dx.doi.org/10.47653/farm.v7i2.283
}

\begin{abstract}
ABSTRAK
Kerang hijau sangat digemari oleh masyarakat karena harga yang lebih murah dari ikan. Kualitas kerang hijau dapat menurun jika ada pencemaran logam berat seperti timbal dan kadmium dalam perairan yang mempunyai dampak buruk bagi kesehatan manusia. Penelitian ini bertujuan untuk mengetahui kadar timbal dan kadmium pada kerang hijau (Perna viridis L.) di perairan kabupaten Tangerang menggunakan metode spektrofotometri serapan atom. Sampel yang dianalisis sebanyak 6 sampel kerang hijau sebelum dan sesudah perebusan. Hasil analisis kandungan timbal dan kadmium pada kerang hijau di perairan kabupaten Tangerang yaitu tidak terdeteksi adanya kandungan timbal dan kadmium didalamnya, tetapi untuk mengetahui perairan yang menghasilkan hasil analisis terbesar maka harus dihitung hasil konsenterasi sebenarnya yang dihasilkan dan hasil rata-rata konsenterasi yaitu analisis timbal pada kerang hijau di perairan Kronjo 0,1695, Tanjung Kait -0,1288 dan Cituis $-0,08065 \mathrm{mg} / \mathrm{kg}$. Sedangkan untuk nilai rata-rata konsenterasi Kadmium pada perairan Kronjo $-0,6699 \mathrm{mg} / \mathrm{kg}$, Tanjung Kait $-0,5052$ dan Cituis $-0,4280 \mathrm{mg} / \mathrm{kg}$. Sedangkan hasil sesudah perebusan pada kerang hijau yaitu hasil rata-rata analisis timbal pada perairan Kronjo 0,15558 mg/kg, Tanjung Kait 0,1998 dan Cituis $-0,09997 \mathrm{mg} / \mathrm{kg}$, sedangkan dalam analisis Kadmium yaitu perairan Kronjo -0,5868, Tanjung kait -0,5943 dan Cituis $-0,658 \mathrm{mg} / \mathrm{kg}$.
\end{abstract}

Kata Kunci: Kerang hijau (Perna viridis L.), Pencemaran, Spektofotometri Serapan Atom (SSA)

\section{ABSTRACT}

Green mussels are very popular with the community because of the lower prices of fish. The quality of green mussels can decrease if there is heavy metal pollution such as lead and cadmium in waters that have a negative impact on human health. This study aims to determine the levels of lead and cadmium in green mussels (Perna viridis L.) in Tangerang regency waters using atomic absorption spectrophotometry. The samples analyzed were six samples of green mussels before and after boiling. The results of the analysis of lead and cadmium content in green mussels in Tangerang regency waters are not detected the presence of lead and cadmium content in it, but to find out the waters that produce the largest analysis results, it must be calculated the actual results of the results of the concentration and the average results of the concentration of the analysis lead in green mussels in Kronjo waters 0,1695, Tanjung Kait -0,1288 and Cituis -0,08065 mg/kg, cadmium concentration in Kronjo waters -0,66699, Tanjung Kait -0,5052 and Cituis -0,4280 mg/kg. While the results after boiling the green mussels are the average results of lead analysis in kronjo waters 0,15558, Tanjung Kait 0,1998 and Cituis $-0,09997 \mathrm{mg} / \mathrm{kg}$, cadmium analysis Kronjo waters -0.5868 , Tanjung Kait -0, 5943 and Cituis -0,658 mg/kg.

Keywords: Green mussels (Perna viridis L.), Pollution, Atomic Absorption Spectrophotometry (AAS)

\section{PENDAHULUAN}

Kerang hijau merupakan salah satu kerang yang digemari oleh masyarakat selain

karena harganya yang murah tetapi juga memiliki kandungan gizi yang tinggi. Dilihat 
dari sumber energi, kandungan protein kerang hijau $21,9 \%$; lemak $14,5 \%$ dan karbohidrat $18,5 \%$ ini setara dengan kandungan gizi daging sapi dan telur ayam. Jadi tidak heran jika kerang hijau menjadi salah satu menu favorit restoran-restoran makanan laut (Anonim, 2009 dalam Mudinah, 2009).

Menurut Dinas Kelautan dan Perikanan Provinsi Banten tahun 2012, kabupaten Tangerang merupakan wilayah terbesar yang memproduksi kerang hijau di provinsi Banten, menurut Effendi (2003) Kerang hijau mempunyai sifat penyaring (filter feeder), dimana cara mendapatkan makanan dengan cara memompa air melalui rongga mantel sehingga mendapatkan partikel-partikel yang ada dalam air. Pencemaran dalam perairan dapat mempengaruhi kualitas dari kerang hijau tersebut, pencemaran air diakibatkan oleh masuknya bahan pencemar (polutan) yang dapat berupa gas, bahan-bahan terlarut, dan partikulat. Pencemar memasuki badan air dengan berbagai cara, misalnya melalui atmosfer, tanah, limpasan (run off) pertanian, limbah domestik dan perkotaan, pembuangan limbah industri, dan lain-lain.

Logam berat seperti timbal dan kadmium sering mencemari lingkungan perairan dari berbagai macam aktivitas manusia contohnya transportasi laut antar pulau, kegiatan galangan kapal seperti sisa bahan bakar, oli, asap yang berasal dari kapal hingga cat warna pada kapal dan aktivitas industri seperti industri baterai, makanan dan minuman yang menghasilkan limbah kemudian dibuang ke sungai lalu bermura ke pantai (Simbolon dkk, 2014). Dampak penyakit karena tercemarnya logam berat seperti timbal dan kadmium diantaranya adalah kerusakan pada otak, kerusakan pada sistem endokrin, kerusakan pada jantung hingga mengakibatkan kematian (Palar, 2005).

Penentuan kadar logam berat timbal dan kadmium dapat menggunakan spektrofotometri serapan atom (SSA). Spektrofotometri serapan atom digunakan untuk analisis kuantitatif unsur-unsur logam dalam jumlah sekelumit (trace) karena mempunyai kepekaan yang tinggi, pelaksanaanya relatif sederhana dan interferensinya sedikit (Gandjar dan Rohman, 2012).

\section{METODE PENELITIAN}

Penelitian dilaksanakan pada bulan Januari - Juli 2020 dan sampel dianalisis di Laboratorium Terpadu Insitut Pertanian Bogor
Baranangsiang di JI. IPB BS No. 1 Rt 02/05, Tegallega, Kec. Bogor Tengah, Kota Bogor, Jawa Barat.

\section{Alat}

Alat-alat yang digunakan dalam penelitian ini adalah spektrofotometer serapan atom (SSA) agilent tipe 200, neraca analitik, tabung digestion, erlenmeyer $250 \mathrm{ml}$, bulp, pipet volume $10 \mathrm{ml}$ dan $25 \mathrm{ml}$ terkalibrasi, batang pengaduk gelas, pemanas listrik, gelas ukur $100 \mathrm{ml}$, labu ukur $100 \mathrm{ml}$ terkalibrasi, corong gelas, kertas whatman no. 40, pipet tetes, botol sampel uji, kompresor udara dan gas asetilen.

\section{Bahan}

Bahan-bahan yang digunakan adalah $\mathrm{HNO}_{3}$ pekat, $\mathrm{HClO}_{4} 70-72 \%, \mathrm{H}_{2} \mathrm{O}$ dan larutan standar $\mathrm{Pb}$ dan larutan standar $\mathrm{Cd}$.

\section{Metode}

Penyediaan larutan standar timbal dan kadmium dengan konsentrasi 10 ppm. Larutan standar untuk masing-masing logam di encerkan dengan berbagai variasi konsentrasi.

Preparasi sampel dilakukan dengan menggunakan metode dektruksi basah, pertama yang dilakukan adalah timbang sampel sebanyak 1-2,5 g dalam erlenmeyer atau tabung digestion kemudian tambahkan 25 $\mathrm{ml} \mathrm{HNO}_{3}$ pekat lalu biarkan semalam, selanjutnya didihkan perlahan selama 35 menit untuk menghilangkan semua senyawa yang mudah teroksidasi, kemudian dinginkan larutan dan tambahkan $10 \mathrm{~mL} \mathrm{HClO}_{4} 70-72 \%$ dan didihkan dengan suhu $100{ }^{\circ} \mathrm{C}$ secara perlahan sampai didihkan kembali sampai semua gas $\mathrm{NO}_{2}$ keluar, setelah itu dinginkan lalu difiltrasi ke dalam labu ukur $50 \mathrm{~mL}$, encerkan sampai tanda tera, lalu homogenkan dan larutan siap uji.

Sampel yang telah dipreparasi selanjutnya dianalisis dengan Spektrofotometri Serapan Atom (SSA) agilent tipe 200, prosedur kerja untuk pengoprasian analisis tersebut dengan memakai panjang gelombang yang sesuai yaitu untuk timbal $217 \mathrm{~nm}$ dan kadmium 228,8 $\mathrm{nm}$.

\section{Teknik Analisis Data}

Teknik yang digunakan dalam analisis ini adalah metode kurva kalibrasi. Kurva standar terdapat hubungan antara konsenterasi (C) dengan absorbansi (A) maka nilai yang dapat diketahui adalah nilai slope dan intersep, 
kemudian nilai konsenterasi sampel diketahui dengan memasukkan kedalam persamaan regresi liniear dengan menggunakan hukum Lambert-Beer yaitu :

$y=b x+a$

Dimana:

$y=$ Menyatakan absorbansi sampel

$\mathrm{b}=$ Koefisien regresi (menyatakan slope $=$ kemiringan)

$x=$ Konsentrasi sampel

$a=$ Tetapan regresi (menyatakan intersep)

Sampel dalam penelitian ini akan mendapatkan 2 kali perlakuan, sampel yang dianalisis yaitu kerang hijau yang berasal dari perairan kabupaten Tangerang. Data yang didapat setelah dilakukan pengujian dengan Spektrofotometri Serapan Atom (SSA) akan dimasukkan ke dalam table yang telah disediakan untuk kemudian dianalisa.

\section{HASIL DAN PEMBAHASAN}

Hasil analisis kandungan timbal dan kadmium pada kerang hijau di perairan kabupaten Tangerang yaitu tidak terdeteksi adanya kandungan timbal dan kadmium didalamnya, tetapi untuk mengetahui perairan yang menghasilkan hasil analisis terbesar maka harus dihitung hasil konsenterasi sebenarnya yang dihasilkan.

Tabel 1. Hasil konsenterasi sebenarnya dalam analisis timbal pada kerang hijau sebelum perebusan di perairan kabupaten Tangerang.

\begin{tabular}{cccc}
\hline Perairan & Replikasi & $\begin{array}{c}\text { Konsenterasi } \\
\text { sebenarnya } \\
\text { (mg/kg) }\end{array}$ & $\begin{array}{c}\text { Rata-rata } \\
\text { konsenterasi } \\
\text { sebenarnya (mg/kg) }\end{array}$ \\
\hline Kronjo & 1 & 0,2269 & 0,1695 \\
& 2 & 0,1121 & \\
Tj. Kait & 1 & $-0,1707$ & $-0,1288$ \\
Cituis & 2 & $-0,087$ & $-0,08065$ \\
\hline
\end{tabular}

Berdasarkan Tabel 1. Hasil konsenterasi sebenarnya pada analisis timbal memperlihatkan bahwa perairan Kronjo lebih besar dibandingkan dengan perairan lainnya yaitu 0,2269 dan $0,1121 \mathrm{mg} / \mathrm{kg}$ dengan hasil rata-rata $0,1695 \mathrm{mg} / \mathrm{kg}$, terbesar kedua adalah perairan Cituis dengan hasil 0,215 dan $-0,3763$ $\mathrm{mg} / \mathrm{kg}$ dengan hasil rata-rata $-0,08065 \mathrm{mg} / \mathrm{kg}$ dan urutan terakhir yaitu perairan Tanjung kait dengan hasil $-0,1707$ dan $-0,087 \mathrm{mg} / \mathrm{kg}$ dengan rata-rata $-0,1288 \mathrm{mg} / \mathrm{kg}$.

Tabel 2. Hasil konsenterasi sebenarnya dalam analisis kadmium pada kerang hijau sebelum perebusan di perairan kabupaten Tangerang.

\begin{tabular}{cccc}
\hline Perairan & Replikasi & $\begin{array}{c}\text { Konsenterasi } \\
\text { sebenarnya } \\
\text { (mg/kg) }\end{array}$ & $\begin{array}{c}\text { Rata-rata } \\
\text { konsenterasi } \\
\text { sebenarnya (mg/kg) }\end{array}$ \\
\hline Kronjo & 1 & $-0,6635$ & $-0,6699$ \\
Tj. Kait & 2 & $-0,6763$ & $-0,5052$ \\
Cituis & 2 & $-0,4781$ & $-0,4280$ \\
\hline
\end{tabular}

Berdasarkan Tabel 2. Hasil konsenterasi sebenarnya memperlihatkan bahwa hasil terbesar adalah perairan Cituis dengan hasil 0,3788 dan $-0,4773 \mathrm{mg} / \mathrm{kg}$ dengan rata-rata $0,4280 \mathrm{mg} / \mathrm{kg}$ lalu selanjutnya Tanjung Kait dengan hasil $-0,4781$ dan $-0,5324 \mathrm{mg} / \mathrm{kg}$ dengan rata-rata yaitu $0,5052 \mathrm{mg} / \mathrm{kg}$ dan urutan terakhir yaitu perairan Kronjo dengan hasil $-0,6635$ dan $-0,6763 \mathrm{mg} / \mathrm{kg}$ dengan hasil rata-rata $-0.6699 \mathrm{mg} / \mathrm{kg}$. 
Tabel 3. Hasil konsenterasi sebenarnya dalam analisis timbal pada kerang hijau sesudah perebusan di perairan kabupaten Tangerang

\begin{tabular}{cccc}
\hline Perairan & replikasi & $\begin{array}{c}\text { Konsenterasi } \\
\text { sebenarnya } \\
\mathbf{( m g / k g )}\end{array}$ & $\begin{array}{c}\text { Rata-rata } \\
\text { konsenterasi } \\
\text { sebenarnya (mg/kg) }\end{array}$ \\
\hline Kronjo & 1 & 0,2173 & 0,1558 \\
Tj. Kait & 2 & 0,0943 & 0,1998 \\
& 2 & 0,4963 & $-0,0977$ \\
Cituis & 1 & $-0,0966$ & $-0,5323$ \\
\hline
\end{tabular}

Berdasarkan Tabel 3. memperlihatkan bahwa perairan Tanjung kait lebih besar dari pada perairan yang lain yaitu dengan hasil 0,4963 dan $-0,0966 \mathrm{mg} / \mathrm{kg}$ dengan rata-rata $0,1998 \mathrm{mg} / \mathrm{kg}$, hasil tersebut berbanding jauh dengan hasil sebelum perebusan yaitu dengan rata-rata $-0,1288 \mathrm{mg} / \mathrm{kg}$ yang memperlihatkan hasil tidak mengalami penurunan.

Terbesar kedua yaitu perairan Kronjo dengan hasil 0,2173 dan 0,0943 mg/kg dengan rata-rata $0,1558 \mathrm{mg} / \mathrm{kg}$ dan hasil rata-rata konsenterasi sebenarnya sebelum perebusan yaitu $0,1695 \mathrm{mg} / \mathrm{kg}$. Lalu urutan terakhir yaitu pada perairan Cituis dengan hasil $-0,5323$ dan $0,3369 \mathrm{mg} / \mathrm{kg}$ dengan rata-rata $-0,9777$ dan hasil sebelum perebusan dengan rata-rata $0,08065 \mathrm{mg} / \mathrm{kg}$, hasil tersebut menunjukkan terjadi penurunan pada hasil 2 perairan tersebut karena sebelum perebusan lebih besar dibandingkan sesudah perebusan.

Tabel 4. Hasil konsenterasi sebenarnya dalam analisis kadmium pada kerang hijau sesudah perebusan di perairan kabupaten Tangerang

\begin{tabular}{cccc}
\hline Perairan & Replikasi & $\begin{array}{c}\text { Konsenterasi } \\
\text { sebenarnya } \\
\text { (mg/kg) }\end{array}$ & $\begin{array}{c}\text { Rata-rata } \\
\text { konsenterasi } \\
\text { sebenarnya (mg/kg) }\end{array}$ \\
\hline Kronjo & 1 & $-0,6211$ & $-0,5868$ \\
& 2 & $-0,5525$ & \\
Tj. Kait & 1 & $-0,5672$ & $-0,5943$ \\
Cituis & 2 & $-0,6214$ & $-0,658$ \\
\hline
\end{tabular}

Berdasarkan Tabel 4. Memperlihatkan bahwa perairan Kronjo lebih besar hasil yang diperoleh daripada perairan yang lain yaitu 0,6211 dan $-0,5525 \mathrm{mg} / \mathrm{kg}$ dengan rata-rata $0,5868 \mathrm{mg} / \mathrm{kg}$ dan hasil sebelum perebusannya yaitu dengan rata-rata $-0,6699$ berdasarkan hasil tersebut maka tidak terjadi penurunan pada kerang hijau sesudah perebusan.

Terbesar kedua yaitu perairan Tanjung Kait dengan hasil $-0,5672$ dan $-0,6214 \mathrm{mg} / \mathrm{kg}$ dengan rata-rata $-0,5943 \mathrm{mg} / \mathrm{kg}$ dan hasil sebelum perebusannya yaitu dengan rata-rata $-0,5052 \mathrm{mg} / \mathrm{kg}$. Hasil terendah yaitu pada perairan Cituis dengan hasil -0,6325 dan $0,6835 \mathrm{mg} / \mathrm{kg}$ dengan rata-rata $-0,658 \mathrm{mg} / \mathrm{kg}$ dan rata-rata hasil sebelum perebusannya adalah -0,4196 $\mathrm{mg} / \mathrm{kg}$ berdasarkan hal tersebut menunjukkan bahwa hasil pada 2 perairan tersebut mengalami penurunan pada kerang hijau sesudah perebusan.

Pada analisis timbal dan kadmium kerang hijau sebelum dan sesudah perebusan, ada beberapa hasil konsenterasi sebenarnya yang menghasilkan hasil yang minus (-) dikarenakan konsenterasi kandungan $\mathrm{Pb}$ dan $\mathrm{Cd}$ pada sampel tidak terbaca oleh alat, dimana absorbansinya berada dibawah batas deteksi Spektrofotometri serapan atom (SSA) untuk $\mathrm{Pb}$ yaitu $<0,4$ Sedangkan untuk $\mathrm{Cd}<0,1$.

Berdasarkan hasil yang telah dijelaskan sebelumnya analisis $\mathrm{Pb}$ pada perairan Tanjung Kait dan hasil analisis $\mathrm{Cd}$ pada perairan Kronjo pada kerang hijau sesudah perebusan tidak mengalami penurunan. Faktor-faktor yang menyebabkan kesalahan hasil dalam analisis $\mathrm{Pb}$ dan $\mathrm{Cd}$ pada kerang hijau sesudah perebusan, faktor pertama 
peneliti tidak mengukur suhu pada saat perebusan hanya mengandalkan waktu yang telah ditentukan saja sehingga suhu yang digunakan pada saat proses perebusan tidak diketahui.

Hal tersebut didukung oleh penelitian Nurdiyanti, nanis. dkk (2017) tetapi dengan metode pengukusan, bahwa tidak diukurnya suhu saat proses pengukusan juga mendukung kadar timbal $(\mathrm{Pb})$ pada setiap perlakuan dan pengulangan mengalami penurunan maupun kenaikan.

Menurut Rahmawati, (2013) menyatakan alasan terlepasnya timbal dari kerang darah dikarenakan adanya suhu yang tinggi sehingga semakin banyak ion yang mampu terlepas dan terpecah dari ikatan kompleks dengan protein.

Menurut Ersoy dan Ozeren (2009) pengolahan bahan pangan dengan menggunakan suhu tinggi dapat menyebabkan terjadinya penguapan air pada bahan pangan tersebut, semakin tinggi suhu yang digunakan semakin banyak pula molekul-molekul air yang keluar dari permukaan bahan pangan, diantaranya mineral yang ikut terlarut bersama dengan air.

Faktor kedua yang menyebabkan kesalahan dalam analisis $\mathrm{Pb}$ dan $\mathrm{Cd}$ pada kerang hijau sesudah perebusan adalah air yang digunakan dalam proses perebusan adalah air yang biasa digunakan sehari-hari.

Hal tersebut didukung oleh penelitian Ariska Pipit (2018) yaitu sampel air tanah di uji secara kualitatif yang terdapat di 3 titik kelurahan Mojosongo kota surakarta positif mengandung logam Fe (Besi) dan sampel air tanah di uji secara kuantitatif di dapatkan kadar logam besi pada 3 titik kelurahan mojosongo kota surakarta yaitu (A.A, A.T dan A.B) berturut-turut sebagai berikut : $0,2071 \mathrm{mg} / \mathrm{L}$, $0,1786 \mathrm{mg} / \mathrm{L}$, dan $0,2753 \mathrm{mg} / \mathrm{L}$. Kadar besi yang terkandung dalam air tanah di daerah mojosongo kota surakarta masih memenuhi syarat menurut Peraturan Menteri Kesehtan Nomor: 32 Tahun 2017 adalah 1,0 mg/L.

Berdasarkan penelitian tersebut air yang berasal dari tanah bisa dapat mengandung logam berat. Oleh karena itu, hasil kerang hijau sesudah perebusan lebih besar dari sebelum perebusan hal tersebut diduga karena dalam air tersebut mengandung logam berat.

\section{KESIMPULAN}

1. Tidak terdapat kandungan timbal dan kadmium pada kerang hijau di perairan kabupaten Tangerang.

2. Hasil rata-rata konsenterasi timbal dan kadmium pada kerang hijau di perairan Kronjo, Tanjung Kait dan Cituis masih dibawah batas maksium yang telah ditetapkan oleh BPOM.

3. Hasil rata-rata konsenterasi $\mathrm{Pb}$ (sebelum perebusan) terbesar terdapat pada perairan Kronjo, kemudian Cituis dan urutan terakhir yaitu perairan Tanjung Kait, sedangkan pada Cd (sebelum perebusan) terbesar terdapat pada perairan Cituis, selanjutnya perairan Tanjung Kait dan terakhir perairan Kronjo. Hasil rata-rata konsenterasi $\mathrm{Pb}$ pada kerang hijau (sesudah perebusan) terbesar terdapat pada perairan Tanjung Kait, lalu Kronjo dan terakhir Cituis. Sedangkan pada $\mathrm{Cd}$ terbesar terdapat pada perairan Kronjo, lalu Tanjung Kait dan terakhir Cituis.

4. Hasil analisis timbal dan kadmium pada kerang sebelum perebusan lebih besar dibandingkan sesudah perebusan hanya pada perairan Tanjung Kait untuk analisis timbal dan perairan kronjo untuk analisis kadmium yang tidak mengalami penurunan.

\section{SARAN}

Diharapkan pada penelitian selanjutnya dapat menganalisis kandungan logam berat dan biota laut yang lain karena perairan kabupaten Tangerang mempunyai banyak sekali keanekaragaman hasil laut yang dihasilkan dan dapat menggunakan ICP-MS atau ICP-OES.

\section{DAFTAR PUSTAKA}

Ariska, Pipit. 2018. Penetapan Kadar Fe (besi) pada Air Tanah Di Kelurahan Mojosongo Kota Surakarta Dengan Metode Spektrofotometri Serapan Atom. Jurnal. Program Studi D-lii Analis Kesehatan Fakultas IImu Kesehatan Universitas Setia Budi. Surakarta.

BPOM. 2018. Peraturan Badan Pengawas Obat Dan Makanan Nomor 5 Tahun 2018 Tentang Batas Maksimum Cemaran Logam Berat Dalam Pangan Olahan. Jakarta : BPOM RI.

Effendi, H. 2003. Telaah kualitas air bagi pengelola sumber daya dan lingkungan perairan. Yogyakarta : Kanisius. 
Ersoy B,Ozeren A. 2009. The Effect Of Cooking Methods On Mineral And Vitamin Contents Of African Catfish. Food Chemistry, $115: 419-422$.

Gandjar Dan Rohman. 2012. Analisis Obat. Yogyakarta: Pustaka Pelajar.

Mudinah. 2009. Penanganan Dan Diversifikasi Produk Olahan Kerang Hijau Vol. 4 NO. 2. Jurnal. Balai Besar Riset Pengolahan Produk Dan Bioteknologi Kelautan Dan Perikanan.

Nurdiyanti, Nanis, Dkk. 2017. Kadar Timbal (Pb) Pada Daging Kerang Darah Bercangkang Dan Tidak Bercangkang Setelah Pengukusan Dengan Air Yang
Ditambahkan Asam Jawa (Tamarindus Indica L.). Jurnal. Surabaya: Jurusan Analis Kesehatan Poltekkes Kemenkes Surabaya.

Palar, D. H. 2012. Pencemaran Dan Toksikologi Logam Berat. Jakarta: Pt. Rineka Cipta.

Simbolon dkk. 2014. Status Pencemaran Dan Kandungan Logam Berat Pada Simping ( Placuna Placenta ) Di Pesisir Kabupaten Tangerang Status Pollution and Heavy Metal Content on Scallop ( Placuna Placenta ) in Tangerang Coastal Waters. 3(2): 91-98. 